\title{
HUKUM ISLAM PERSPEKTIF PARADIGMA BARU KEILMUAN
}

\author{
Muhammad Ilham \\ Institut Agama Islam (IAI) Muhammadiyah Bima \\ Jl. Anggrek No. 16 Ranggo Na'e Kota Bima \\ Email:ilhamsmsfc16@gmail.com
}

\begin{abstract}
Abstrak
Hukum yang diperkenalkan oleh al Qur'an bukanlah sesuatu yang berdiri sendiri, tetapi merupakan bagian integral dari aqidah yang diimani. Dengan perkembangan metode taqnin dan dibukanya kembali pintu ijtihad, maka paradigma keilmuan dalam hukum Islam pun berjalan terus memenuhi tuntutan kebutuhan manusia dan terus beradaptasi dengan perkembangan sains moderen, lahirlah empat produk pemikiran hukum Islam, yaitu fiqh, fatwa ulama, putusan pengadilan (yurisprudensi) dan undang-undang. Dalam tinjauan epistemologi hukum Islam, dikenal kurang lebih tujuh metode yang digunakan para ulama mujtahid untuk menetapkan dan menerapkan pemikiran hukum Islam, yaitu; Ijma', Qiyas, Istidal, Maslahah al-Mursalah, Istihsan, Istishab dan Adat-istiadat atau 'Urf. Prinsip-prinsip dasar yang digunakan sebagai jaminan kebenaran bagi paradigma keilmuan moderen yang dimaksud adalah obyektif, empiris, deskriptif dan rasional (logic).
\end{abstract}

Keywords: Hukum Islam, Paradigma, Keilmuan.

PENDAHULUAN

A. Latar Belakang 
Hukum yang diperkenalkan oleh al Qur'an bukanlah sesuatu yang berdiri sendiri, tetapi merupakan bagian integral dari aqidah yang diimani. Aqidah tentang Allah yang menciptakan alam semesta, mengatur, memelihara dan menjaganya sehingga segala makhluk itu menjalani kehidupannya dengan baik dan melakukan fungsinya masingmasing dengan tertib.

Penemuan hukum-hukum alam memberikan informasi yang jelas kepada kita betapa alam raya ini bergerak menurut ketentuan-ketentuan hukum alam yang mengaturnya. Selanjutnya hukum yang mengatur kehidupan manusia ini kadang memiliki perbedaan mendasar, yaitu menyangkut pemahaman hukum menurut ilmu hukum dengan hukum Islam yang bersumber dari al Qur'an. Menurut ilmu hukum, hukum itu hanya mengurus dan mengatur hubungan antar sesama manusia. Hukum itu hanya terdiri dari suruhan atau perintah dan larangan serta hak dan kewajiban. Apa yang dimaksud dengan nilai moral dan akhlak tidak tergolong hukum. Sebaliknya hukum menurut ajaran Alquran (hukum Islam), penegakan hukum berjalan sekaligus dengan pembinaan moral atau akhlak yang bersumber dari aqidah. ${ }^{1}$

Seiring dengan perkembangan metode taqnin dan dibukanya kembali pintu ijtihad, maka paradigma keilmuan dalam hukum Islam pun berjalan terus memenuhi tuntutan kebutuhan manusia dan terus beradaptasi dengan perkembangan sains moderen. Sebagai konsekwensinya lahirlah beberapa produk pemikiran hukum Islam, yang oleh Ahmad Rafiq menyebutnya ada empat, yaitu figh, fatwa ulama, putusan pengadilan (yurisprudensi) dan undang-undang. ${ }^{2}$

1 Ali. Yafie, "Ke Arah Kontekstualisasi Fiqh", (Jakarta: al- Hikmah, 1994), h. 104.

2 Ahmad Rafiq, Hukum Islam di Indonesia (Cet. III; Jakarta: Raja Grafindo Persada, 1998), h. 8. 
Indonesia yang mayoritas penduduknya beragama Islam juga sangat membutuhkan produk-produk hukum yang sejalan dengan tuntutan kebutuhan masyarakat. Oleh karena itu, keempat produk pemikiran hukum Islam di atas harus berjalan secara sinerjik sesuai kebutuhan hukum masyarakat Islam Indonesia. Akan tetapi bila dicermati lebih jauh, produk-produk pemikiran hukum Islam ini seringkali tidak menyentuh rasa keadilan masyarakat. Itu disebabkan karena hukum tidak dilandaskan pada sebuah konsepsi kebutuhan hukum kontemporer dengan menyertakan pertimbangan visi hukum dan visi sosial. Itulah sebabnya ia tidak menjadi aplikatif dan responsif terhadap irama perkembangan masyarakat.

Apapun produk hukum pasti bersentuhan dengan kehidupan masyarakat. Terlebih lagi jika hukum tersebut berada pada kerangka pemikiran manusia, karena hal ini akan berkembang mengikuti perkembangan tingkat kecerdasan masyarakat dimana hukum itu diberlakukan. Dalam hal ini salah satu problem yang dihadapi ketika hendak diberlakukan suatu produk hukum adalah adanya ketidaksesuaian dengan kerangka teori keberlakuan hukum dan kurang memperhatikan paradigma keilmuan. ${ }^{3}$

Menggunakan pendekatan paradigma keilmuan yaitu paradigma analitis, kritis, metodologis, historis dan empiris. ${ }^{4}$ Maka dapat diketahui kerangka pengujian terhadap efektifitas penerapan pemikiran hukum Islam. Dengan kata lain produk hukum tersebut harus dapat dianalisa secara kritis, metodologis, mengandung aspek historis dan empiris, sehingga bersifat rasional dan bisa diuji kebenarannya secara ilmiah.

3Soejono Soekamto, Kamus Sosiologi, (Cet. I; Jakarta: Rajawali Press, 1983), h. 14.

4 Abuddin Nata, Metodologi Studi Islam, (Cet. IV; Jakarta: Raja Grafindo Persada, 2000), h. 102

Sangaji Jurnal Pemikiran Syariah dan Hukum 
Dalam hal ini figh dan fatwa sebagai hasil pemikiran cemerlang dari ulama harus dapat menunjukkan aspek rasionalitasnya yang siap diuji oleh perkembangan keilmuan moderen. Demikian pula dengan yurisprudensi dan undangundang sebagai produk pemikiran para hakim dan legislatif yang ditunjuk harus pula menampakkan aspek ilmiah dan fungsionalisasinya pada setiap perkembangan pemikiran manusia. Standar yang digunakan adalah melalui kerangka berfikir keilmuan atau paradigma sains.

\section{B. Rumusan Masalah}

1. Bagaiaman Ontologi Pemikiran Hukum Islam?

2. Bagaimana Epistimologi Penetapan dan Penerapan Pemikiran Hukum Islam?

3. Bagaimana Aksiolgi Pemikiran Hukum Islam?

4. Bagaiaman Paradigma Keilmuan Moderen dan Implikasinya pada Pemikiran Hukum Islam?

\section{PEMBAHASAN}

\section{A. Ontologi Pemikiran Hukum Islam}

Ontologi menurut bahasa berasal dari kata "onto" yang berarti "ada" dan "logos" yang berarti "pikiran". 5 Dalam kamus filsafat disebutkan, kata "ontos" berarti "berbeda" sedang "logos" artinya "ilmu pengetahuan, ajaran atau teori". ${ }^{6}$ Selanjutnya, ontologi menurut istilah adalah ilmu hakekat yang menyelidiki alam nyata ini, bagaimana

5 Suparlan Suhartono, Konsep Dasar Filsafat Ilmu Pengetahuan, (Ujung Pandang; Pascasarjana UNHAS, 1997), h. 77

6 Tim Penulis Rosdakarya, Kamus Filsafat, (Cet. I; Bandung; Remaja Rosdakarya, 1995), h. 30 
keadaan yang sebenarnya. ${ }^{7}$

Ontologi dipahami sebagai suatu pengetahuan yang membicarakan tentang hakekat kenyataan yang dapat membedakan anatara yang nyata (the real) dengan yang tidak nyata (the unreal) atau antara kenyataan dengan kenampakan. ${ }^{8}$

Ontologi produk pemikiran hukum tidak hanya memiliki unsur yang sama, baik dari segi obyek, sumber dan metodologi, tetapi juga lebih jauh ontologi hukum juga berusaha menelusuri apa yang ada di balik obyek, sumber dan metode tersebut. Teori klasik Islam, hukum bersumber kepada kehendak Ilahi, sehingga dinyatakan bahwa Pemberi Hukum (al-Hakim) dalam Islam adalah Allah Yang Maha Bijaksana. Oleh karena itu, setiap usaha penemuan hukum Islam, tidak lain merupakan upaya pencarian dan perumusan kehendak Ilahiah. ${ }^{9}$ Kehendak ilahiah itu kemudian dikenal dengan nama syariah. Dengan kata lain bahwa hukum dalam Islam tidak berdiri sendiri. Hukum Islam tegak di atas landasan teologi yang sangat dalam. Oleh karena itu, konsep-konsep hukum dalam Islam secara fundamental dipengaruhi oleh doktrin-doktrin teologi.

Doktrin-doktrin teologi dalam hukum Islam inilah yang kemudian membedakan hukum Islam dengan produk pemikiran hukum sekuler di Barat. Perbedaan itu bukan hanya terletak pada sikap masyarakat di mana hukum itu masingmasing berlaku, tetapi lebih jauh lagi, antara keduanya dibedakan oleh tujuannya masing-masing. Hukum Islam bertujuan untuk membangun kemaslahatan di dunia dan di

7 Jalaluddin, Filsafat Pendidikan (Jakarta: Gaya Media Pratama, 1998), h. 69

8 Louis O Kattsof, Elements of Philosophy, terj: Soejono Soemargo "Pengantar Filsafat", (Cet. IV; Yogyakarta: Tiara Wacana, 1989), h. 193

9 Amir Mu'allim, dan Yusdani, Konfigurasi Pemikiran Islam, (Cet. I; Yogyakarta: UII Press Indonesia, 1999), h. 20

Sangaji Jurnal Pemikiran Syariah dan Hukum 
akhirat sekaligus, sedangkan hukum sekuler hanya untuk kebaikan/keteraturan di dunia semata. ${ }^{10}$

Konsekuensi logisnya adalah bahwa dalam syariat Islam dikenal konsep pahala bagi orang yang menunaikannya dan dosa atas orang yang melanggarnya, yang akibatnya akan dirasakan oleh manusia di akhirat. Sebagai contoh, dapat dilihat pada perintah melakukan shalat. Perintah itu, meskipun sudah diyakini kebenarannya, tetapi dalil tentang wajibnya shalat tetap dalam keadaan zhanniy, karena tidak ada pengertian atau sebutan yang jelas mengenai wajibnya shalat. Tuhan hanya menyebut (dirikanlah shalat) dan tidak menyebut (wajiblah shalat atau diwajibkan shalat bagimu). Dari sini dapat dipahami ada kemungkinan bahwa shalat itu "tidak wajib hukumnya". Kalaupun sebagai ibadah wajib maka hal itu berada pada substansi shalat yaitu usaha meninggalkan perbuatan keji dan mungkar (QS.29:45), bukan pada kayfiyah shalatnya. Belakangan pengertian tentang wajibnya shalat nanti menjadi jelas setelah mendapatkan keterangan dari dalil lain, misalnya tata cara melaksanakan shalat dijelaskan oleh hadishadis Nabi, dan kenyataan bahwa Nabi Saw, sendiri tidak pernah meninggalkan shalat lima waktu, semua ini membuat dalil tentang wajibnya shalat menjadi kuat dan pasti. Hal ini menunjukkan bahwa ayat-ayat Alquran, memang sebagian menjadi pedoman umum (dalam penerapan hukum maupun soal kemasyarakatan) dan sebagian lainnya berfungsi menjadi penjelasan atas yang lain (QS. 2: 185).

Interaksi dasar-dasar hukum tersebut dimaksudkan untuk menetapkan hubungan manusia dengan Tuhan dan hubungan manusia dengan sesama manusia serta alam sekitarnya. Dalam posisi ini, ontologi hukum Islam lebih diarahkan pada

10 Hamka Haq, Filsafat Ushul Fiqih, (Makassar: Yayasan Al-Ahakam, 2000), h. 19 
pembentukan manusia sebagai hamba Tuhan dan manusia sebagai makhluk sosial. Dengan demikian, dari sisi ontologis, produk pemikiran hukum Islam tidak mengalami masalah yang serius, juga belum mempunyai pengaruh signifikan dalam upaya transformasi sosial. Kondisi ini dimungkinkan karena sejak awal obyek kajian hukum Islam adalah Alquran dan Hadis Nabi Saw yang selalu direfleksikan pada dua hubungan, yaitu hubungan dengan Allah dan hubungan dengan sesama manusia.

\section{B. Epistemologi Penetapan dan Penerapan Pemikiran Hukum Islam}

Pada kajian epistemologi, membahas secara mendalam segala proses penyusunan pengetahuan yang benar. Dengan kata lain bahwa epistemologi adalah ilmu pengetahuan yang mengkaji bagaimana cara mendapatkan pengetahuan.

Jika pemaknaan ini dibawa ke dalam pembahasan hukum Islam, maka yang dimaksud epistemologi penetapan dan penerapan hukum Islam adalah bagaimana mengetahui pesanpesan syar'i (Tuhan sebagai pembuat hukum), dan RasulNya Muhammad saw, melalui firman yang termaktub di tengah kehidupan masyarakat yang terus berkembang.

Sejak dunia Islam bersentuhan dengan filsafat Yunani pada abad pertengahan, lalu kemudian muncullah filosoffilosof Islam kenamaan seperti al-Kindi, al-Farabi, Ibnu Sina, alGhazali dan Ibnu Rusyd, sejak itu maka teori pengetahuan pun berkembang di dunia Islam, seperti pengetahuan rasional, pengetahuan inderawi (empirisme) dan pengetahuan Kasyb yang diperoleh melalui ilham.

Secara garis besar sejak periode yang paling awal, setelah wafatnya Rasulullah para ulama telah merumuskan sumber hukum Islam (al-Quran dan Hadis). Namun dalam 
perkembangan selanjutnya terjadi semacam perbedaan dalam merumuskan dua sumber di atas, yakni berhadapan dengan unsur-unsur otonomi manusia.

Perbedaan-perbedaan itu selanjutnya terjadi karena: Perbedaan dalam memberikan arti bahasa, cara penerimaan suatu Hadis, penyelesaian nash yang saling bertentangan, perbedaan dalam penggunaan qiyas, perbedaan dalam menggunakan dalil tertentu, misalnya istihsan, istishab dan istislah, dan perbedaan dalam penggunaan dan kedudukan suatu lafal. ${ }^{11}$

M. Arkoun menyebutkan bahwa para ulama-ulama mujtahid pada abad kedua dan ketiga hijriyah telah menerapkan prosedur-prosedur penalaran independent untuk mendeduksikan (istinbath) hukum dengan bertolah dari naskahnaskah (nusus). Prosedur itu ada tiga: Menentukan yang lebih baik (istihsan), menentukan kepentingan yang dianggap baik (istislah), dan penalaran analogis (qiyas). ${ }^{12}$

Dengan demikian, secara epistemologis sebenarnya hukum Islam kaya akan metodologi penalaran dan pembentukan hukum yang digali dari al-Quran dan Sunnah. Meskipun terdapat perdebatan di kalangan ulama menyangkut interaksi nash-nash tersebut dengan pemikiran manusia, namun kesemuanya tegas terangkum dalam dua kata kunci pemikiran muslim, yaitu ijtihad sebagai upaya personal dalam merumuskan ajaran, dan taqlid sebagai ketundukan dengan tulus pada ajaran seorang guru.

Kedua kata kunci tersebut (ijtihad dan taqlid) adalah dua pengertian kolektif yang dapat koeksistensi dalam diri seorang

${ }^{11}$ Nor Ahmad, Efistimologi Syara' Mencari Format Baru Fiqh Indonesia, (Cet. I; Yogyakarta: Walisongo Press, 2000), h. 7

${ }^{12} \mathrm{M}$, Arkoun, Essais Surla Pensee Islamique, terj; Hidayatullah "Membedah Pemikiran Islam" (Cet. I; Bandung: Pustaka, 2000), h. 22 
ulama. Hasbi Ash Shiddieqy, seorang pembaharu dalam alam pikiran Islam Indonesia abad ke 20 khususnya dalam bidang hukum Islam, telah merefleksikan kedua kata kunci tersebut dalam rangka mencari format hukum Islam yang sesuai dengan masyarakat Indonesia.

Upaya yang dilakukan Hasbi dalam penggalian hukum (sebagai hasil refleksinya), sebagaimana dijelaskan oleh putera beliau Nourouzzaman Shiddiqi, bahwa Hasbi menggunakan metode analogi deduksi. Hasbi menggunakan metode komparasi, yakni membandingkan antara satu pendapat dengan pendapat lain dari seluruh aliran hukum yang ada atau pernah ada, dan memilih mana yang lebih baik dan lebih dekat kepada kebenaran dan didukung oleh dalil yang kuat. ${ }^{13}$

Oleh karena itu, dalam tinjauan epistemologi hukum Islam, kita mengenal kurang lebih tujuh metode yang digunakan para ulama mujtahid untuk menetapkan dan menerapkan pemikiran hukum Islam, yaitu;

1. Ijma', adalah persetujuan atau kesesuaian pendapat para ahli mengenai suatu masalah pada suatu tempat di suatu masa. Lebih khusus lagi ijma' adalah ketetapan hati atau kesepakatan para mujtahid dari umat Muhammad saw. pada suatu masa, setelah wafatnya Rasulullah saw. terhadap suatu hukum syara. Ijma' dalam arti kesepakatan seluruh ahli hukum saat ini sulit dicapai mengingat luasnya bagian dunia yang didiami oleh umat Islam, beragamnya sejarah, budaya dan lingkungannya. Oleh karena itu, ijma' yang hakiki hanya mungkin terjadi pada masa kedua khulafaur Rasyidin. Sekarang ijma'

${ }^{13}$ Nourozzaman Shiddiqi, Fiqh Indonesia Penggagas dan Gagasannya, (Cet. I; Yogyakarta: Pustaka Pelajar, 1997), h. 69

Sangaji Jurnal Pemikiran Syariah dan Hukum 
hanya berarti persetujuan dan kesesuaian pendapat di suatu tempat mengenai tafsiran ayat-ayat (hukum) tertentu dalam al-Quran ${ }^{14}$

2. Qiyas ialah mempersamakan hukum peristiwa yang belum ada ketentuannya, karena antara kedua peristiwa tersebut terdapat segi-segi persamaan illat (penyebab atau alasannya). ${ }^{15}$ Qiyas merupakan ukuran akal budi untuk membanding suatu hal dan hal lain. sebagai contoh, adanya larangan meminum khamar. Yang menyebabkan minuman itu dilarang adalah illatnya yakni memabukkan. Oleh karena itu, setiap minuman yang memabukkan, dari apapun dibuat, hukumnya sama dengan khamar, yaitu dilarang untuk diminum. Jadi minuman yang memabukkan itu diqiyaskan dengan khamar sehingga dilarang diminum dan diperjualbelikan untuk umum.

3. Istidal adalah menarik kesimpulan dari dua hal yang berlainan. Misalnya adalah menarik kesimpulan dari adat istiadat dan hukum agama yang diwahyukan sebelum Islam. Adat yang telah lazim dalam masyarakat dan tidak bertentangan dengan hukum Islam (seperti harta gono-gini atau harta bersama) dan hukum agama yang diwahyukan sebelum Islam tetapi tidak dihapuskan oleh syariat Islam, dapat ditarik garis-garis hukumnya untuk dijadikan hukum Islam. ${ }^{16}$

${ }^{14}$ Mohammad Daud Ali, Hukum Islam Pengantar Ilmu Hukum dan Tata Hukum Islam di Indnesia (Cet. IV; Jakarta: Raja Grafindo Persada, 1998), h. 109

15 Ahmad Hafani, Asas-Asas Hukum Pidana Islam, (Cet. V; Jakarta: Bulan Bintang, 1993), h. 33

${ }^{16}$ Mohammad Daud Ali, Hukum Islam Pengantar Ilmu Hukum dan Tata 
4. Maslahah al-Mursalah ialah cara menemukan hukum sesuatu hal yang tidak terdapat ketentuannya, baik dalam Alquran maupun kitab-kitab hadis, berdasarkan pertimbangan kemaslahatan masyarakat atau kepentingan umum. Maslahah al-Mursalah dalam epistemologi hukum Islam secara hakiki meliputi: ${ }^{17}$
a) Keselamatan keyakinan agama;
b) Kesehatan jiwa;
c) Keselamatan akal;
d) Keselamatan keluarga dan keturunan;
e) Keselamatan harta benda.

5. Istihsan ialah metode penetapan hukum suatu masalah dan meninggalkan yang lainnya, karena adanya indikasi yang lebih kuat dan lebih bersifat khusus. ${ }^{18}$ Dengan kata lain bahwa istihsan adalah cara menetapkan hukum dengan jalan menyimpang dari ketentuan yang sudah ada demi keadilan dan kepentingan sosial.

6. Istishab adalah menetapkan hukum sesuatu hal menurut keadaan yang terjadi sebelumnya, sampai ada dalil yang mengubahnya. Atau dengan kata lain istishab adalah melangsungkan berlakunya hukum yang telah ada karena belum ada ketentuan lain yang membatalkannya.

7. Adat-istiadat atau 'Urf yaitu kebiasaan mayoritas kaum, baik dalam perkataan maupun perbuatan. 'Urf adalah

Hukum Islam di Indnesia (Cet. IV; Jakarta: Raja Grafindo Persada, 1998), h. 110

${ }^{17}$ Muhammad Abu Zahra, Ushul Fiqih, (Cet. VI; Jakarta: Pustaka Firdaus, 2000), h. 425

18 Zarkasyi Abdul Salam, Figh-Ushul Figh, (Yogyakarta: Lembaga Studi Filsafat Islam, 1994), h. 113

Sangaji Jurnal Pemikiran Syariah dan Hukum 
suatu metode penetapan hukum Islam selama tidak bertentangan dengan nash. Para ulama menerimanya sebagai dalil hukum yang tidak mandiri, tetapi harus terkait dengan dalil lain yang sunnah. ${ }^{19}$

Jika epistemologi hukum Islam di atas dapat dikembangkan oleh para ulama mujtahid kita sekarang, maka tidak ada masalah yang timbul dalam masyarakat yang tidak dapat dipecahkan dan ditentukan hukumnya.

Dengan demikian, upaya pengembangan epistemologi hukum Islam adalah suatu kebutuhan umat yang harus dipenuhi. Akan tetapi dalam penerapan hukum Islam yang seiring dengan perkembangan iptek dan kebutuhan hukum masyarakat harus memperhatikan asas-asas penerapan syariat yaitu: ${ }^{20}$

1. Tidak memberatkan,

2. Tidak memperbanyak beban,

3. Bertahap.

\section{Aksiologi Pemikiran Hukum Islam}

Menurut Soejono Soekanto konseptual aksiologi hukum Islam itu mempunyai tiga aspek pokok, yaitu: ${ }^{21}$

1. Aspek kognitif

Aspek kognitif ini berkaitan dengan ratio atau pikiran. Misalnya nilai suatu perkawinan menurut adat istiadat dan agama. Secara kognitif perkawinan

${ }_{19}$ Nasrun Rusli, Konsep Ijtihad al-Syaukani, Relevansinya Bagi Pembaharuan Hukum-Hukum Islam di Indonesia, (Cet. I; Jakarta: Logos Wacana ILmu, 1999), 35

${ }^{20}$ Hamka Haq, Filsafat Ushul Fiqih, (Makassar: Yayasan Al-Ahakam, 2000), h. 40

21 Rusli Efendi, Teori Hukum, (Cet. I: Ujung Pandang: Hasanuddin University Press, 1991), h. 35 
merupakan suatu pergaulan antara dua manusia yang berbeda jenisnya, yang dilakukan secara teratur menurut hukum Islam maupun hukum adat yang dianut oleh masyarakat setempat.

2. Aspek Afektif

Aspek ini berkaitan dengan perasaan atau emosi. Misalnya perkawinan di atas juga merupakan pergaulan hidup yang menghasilkan ketentraman pada keluarga yang terbentuk karena perkawinan itu.

3. Aspek Konatif

Aspek Konatif ini berhubungan dengan penyerahan diri kedua aspek sebelumnya, yang berkaitan dengan kehendak (untuk berbuat atau tidak berbuat), Misalnya keserasian antara ketertiban dan keteraturan dalam perkawinan, menghasilkan suatu kehidupan damai dalam keluarga.

Teori-teori hukum, biasanya dibedakan antara empat macam hal hukum sebagai norma (nilai). Empat unsur itu adalah:

1. Norma hukum tersebut berlaku secara filosofis, falsafa, artinya sesuai dengan cita-cita hukum sebagai nilai positif yang tertinggi. Di dalam hukum Islam dikenal dengan "maqasid al-Tasyri" dan "asrar al-Tasyri", yang rumusan hukumnya dibentuk melalui "al-qawa"id alfiqhiyah".

2. Norma hukum berlaku secara "yuridis, ushuliyah, apabila penentuannya didasarkan pada norma yang lebih tinggi tingkatannya dan dibentuk menurut metode yang sahih. Dalam hal hukum Islam, tentu saja berdasarkan alQur"an dan al-Sunnah, dengan memakai metode istinbat, memakai ilmu usul al-Figh dan qawaid al-figh.

Sangaji Jurnal Pemikiran Syariah dan Hukum 
3. Norma hukum berlaku secara "legality, qanuniyah", apabila norma tersebut efektif. Artinya norma tersebut dapat dipaksakan berlakunya oleh penguasa walaupun belum diterima oleh warga masyarakat. Jadi norma hukum itu dilembagakan melalui prosedur perundang-undangan, yang dikenal dalam hukum Islam dengan "al-Taqnin (dilembagakan menjadi undang-undang atau kodifikasi hukum Islam).

4. Norma hukum berlaku secara "sosiologis, waqiah ijtima"iyah ,apabila norma tadi berlaku karena diterima dan diakui oleh masyarakat; hukum yang hidup di tengahtengah masyarakat, hukum Islam di Indonesia sebagian besar masih pada taraf ini, yakni diterima oleh masyarakat Indonesia (umat Islam). ${ }^{22}$

Dari keempat unsur tersebut, untuk dapatnya hukum Islam berfungsi dalam masyarakat harus membutuhkan faktor pendukung, yaitu fasilitas yang diharapkan akan dapat mendukung pelaksanaan norma hukum Islam di tengah-tengah masyarakat.

\section{Telaah Kritis Paradigma Keilmuan Moderen dan Implikasinya pada Pemikiran Hukum Islam.}

Konsep paradigma, pertama kali dikemukakan oleh Thomas S. Kuhn (1962) melalui karyanya yang berjudul "The Structure of Scientific Revolution". ${ }^{23}$ Secara etimologis, paradigma

22 Syechrul Hadi Permana, Peradilan Agama dan Komplikasi Hukum Islam dalm Tata Hukum Indonesia, (Cet. I; Jakarta: UI Press, 1999), h. 130

23 Yusriyadi, Alternatif Pemikiran Tentang Paradigma Ilmu Hukum Indonesia, dalam "Wajah Hukum di Era Reformasi”, (Cet. I Bandung: Citra Aditya 
berasal dari kata-kata dalam bahasa Yunani yaitu "para"(di samping atau berdampingan) dan "deigma" (contoh). Sedang secara terminologi, paradigma adalah pedoman (contoh) yang dipakai untuk menunjukkan sistem pemikiran, bentuk kasus dan pola pemecahannya. ${ }^{24}$

Prinsip-prinsip dasar paradigma sains yang dimaksud adalah obyektif, empiris, deskriptif dan rasional $(\log i c) .{ }^{25}$ Prinsip inilah yang kemudian digunakan sebagai jaminan kebenaran bagi paradigma keilmuan moderen. Untuk lebih jelasnya dapat penulis jabarkan sebagai berikut:

1. Obyektif, yaitu bahwa paradigma keilmuan moderen merupakan satu- satunya ilmu yang otentik, yaitu ilmu yang hanya bersangkut paut dengan fenomena dan dapat berubah dalam zaman yang lain. ${ }^{26}$

2. Empiris, yaitu bahwa apa diterima oleh paradigma keilmuan moderen hanyalah teori-teori yang dapat direduksi kepada unsur-unsur inderawi,walaupun teoriteori itu mungkin melibatkan gagasan-gagasan yang melampaui jangkauan pengalaman empiris. Paradigma keilmuan yang berprinsip pada empiris ini juga selalu menyandarkan seluruh ilmu pada fakta-fakta yang dapat diamati dan dianalisis. ${ }^{27}$

Bakti, 2000), h. 42

24 Partanto Pius A, Kamus Ilmia Populer, (Surabaya: Arkola, 1994), h. 566

${ }^{25}$ Muhaimin dan Abd. Mujib, Pemikiran Pendidikan Islam, Kajian Filosofi dan Kerangka Dasar Operasionalnya, (Cet. I; Bandung: Trigenda Karya, 1993), h. 93

26 Syed Muhammad Naquib Al-Attas, Islam and The Philosophy of Science, terj; Saiful Muzani "Islam dan Filsafat Sains", (Cet. I; Bandung: Mizan, 1995), h. 26

${ }^{27}$ Andi hakim Nasution, Pengantar ke Filsafat Sains, (Cet. I; Bogor: Litera Antar Nusa, 1989), h. 21

Sangaji Jurnal Pemikiran Syariah dan Hukum 
3. Deskriptif, artinya menggambarkan atau menguraikan sesuatu hal menurut apa adanya. ${ }^{28}$ Dalam prinsip ini paradigma keilmuan hanya bisa menjelaskan sesuatu sesuai dengan realitas obyek yang faliditasnya bisa dipertanggungjawabkan.

4. Rasional (logic), yaitu bahwa paradigma keilmuan moderen itu selalu bersandar pada nalar dan dalam menguraikan sesuatu berdasarkan runtut atau urutan pernyataan yang satu dengan pernyataan berikutnya.

Prinsip-prinsip tersebut masing-masing memiliki indikator yang menunjukkan adanya pemaduan paradigma keilmuan moderen dengan paradigma hukum Islam. Konsepsi pemaduan tersebut beserta indikator- indikatornya dapat dijelaskan sebagai berikut:

1. Wahyu, merupakan sumber utama pemikiran hukum Islam menempati posisi paling atas dalam paradigma hukum Islam, baik sebagai induktif maupun deduktif. Sebagai induktif, wahyu dijadikan tempat konsultasi untuk pemikiran hukum ,sedang sebagai deduktif, wahyu dijadikan tempat bertolak lalu diturunkan menjadi acuan ijtihad.

2. Obyektivitas, adalah prinsip keilmuan moderen yang memandang suatu pernyataan keilmuan hanya dibuat atas dasar bukti atau pada hal-hal yang dapat diamati. Dalam Islam obyektivitas suatu hukum, lebih memiliki keberpihakan pada kebenaran dan keadilan, bukan pada kepentingan pemilik bukti- bukti tersebut.

3. Empiris, adalah prinsip paradigma keilmuan moderen yang memandang validitas suatu pernyataan sains bergantung

${ }^{28}$ Partanto Pius A, Kamus Ilmia Populer, (Surabaya: Arkola, 1994), h. 105 
pada bukti-bukti pelaksanaan (yang sudah teruji),tujuannya maupun pandangan orang yang menjalankannya.

4. Deskriptif, adalah prinsip paradigma keilmuan yang hanya dapat menjelaskan sesuatu apa adanya sesuai dengan realitas yang kebenarannya dapat dipertanggungjawabkan. Hal ini penting diperhatikan agar orang melakukan pemaknaan dapat terhindar dari tekanan-tekanan politis dan pisikis yang mungkin bisa mempengaruhi pengambilan sebuah putusan hukum. Oleh karena itu, integritas moral seorang ilmuan dan hakim sangat menentukan tegaknya supremasi hukum negeri ini.

5. Logik, adalah prinsip paradigma keilmuan moderen yang menekankan pada urutan atau runtut suatu pernyataan dengan pernyataan yang lain sehingga terjadinya kesinambungan. Bagi paradigma hukum Islam, lahirnya sebuah produk hukum Islam harus memiliki kesinambungan antara sumber hukum (wahyu) dengan pemikiran hukum (ijtihad), antara kebutuhan hukum masyarakat dengan kemampuan multi-disipliner para mujtahid, dan antara illat hukum yang satu dengan illat hukum yang lain.

Dalam upaya pemaduan paradigma keilmuan moderen dengan paradigma atau pemikiran hukum Islam, maka penulis menawarkan beberapa solusi pendekatan antara lain:

1. Pendekatan Historis ialah dengan mempelajari perkembangan metodologi hukum Islam terutama pada masa awal Islam hingga saat ini guna dijadikan gambaran awal dalam istinbath hukum Islam ke depan.

2. Pendekatan sosio-kultural ialah dengan mempelajari aspek- 
aspek yang melatarbelakangi lahirnya suatu produk hukum Islam. Pendekatan ini juga dimaksudkan untuk mempelajari basic cultural setiap mujtahid, karena hal ini sangat mempengaruhi kerangka berfikir dan visi hukum mujtahid tersebut.

3. Pendekatan teleologis-filosofis ialah dengan melakukan rekonstruksi kaedah-kaedah hukum Islam agar tetap sebagai norma hidup umat yang bisa menjamin keselamatan di dunia dan di akhirat. Rekonstruksi kaedah-kaedah ini dilakukan secara sistematis, radikal dan universal agar norma hukum tersebut terasa sebagai suatu kebutuhan hidup yang hakiki.

4. Pendekatan sains, yaitu dengan melakukan survei disipliner ilmu-ilmu moderen dan analisa khazanah pemikiran hukum Islam sehingga dapat menentukan relevansi pemikiran Islam terhadap disiplin ilmu-ilmu moderen untuk selanjutnya dianalisa dan disintesis, yaitu dengan memadukan antara metode ilmiah(rasional, obyektif, kritis, deskriptif dan logik), dengan metode hukum normatif. Dengan demikian, para mujtahid dan cendekiawan muslim yang fanatik terhadap pemikiran hukum Islam harus memiliki keterbukaan berfikir dengan menghilangkan sikap ketidak terbukaan terhadap metodologi keilmuan Barat. Sikap keterbukaan ini akan membawa wawasan yang luas dan menghindari upaya kristalisasi terhadap mazhab-mazhab tertentu. Olehnya itu, bagi penulis mazhab-mazhab terdahulu itu hanya dapat dijadikan sebagai "manhajadi al-fikr", sedang metodologi keilmuan moderen dapat dikomparasikan untuk mengembangkan hukum Islam di masa mendatang. 


\section{KESIMPULAN}

Pemikiran hukum Islam di Indonesia merupakan upaya maksimal ulama untuk melahirkan suatu mazhab hukum yang sejalan dengan kultur masyarakat Islam Indonesia. Untuk itu, produk pemikiran hukum ini dapat diterapkan, baik secara filosofis, yuridis formal maupun sosiologis-kultural. Selain itu, optimalisasi tradisi ijtihad harus terus dilakukan.

Dengan demikian, peran-peran universal syari'ah dapat diterjemahkan menjadi suatu konfigurasi hukum Islam yang menyentuh rasa keadilan masyarakat dan dapat mengikuti irama perkembangan iptek dan sosial kemasyarakatan di setiap tempat dan zaman.

Salah satu problem irelevansi hukum Islam dengan perkembangan pemikiran dan peradaban manusia sehubungan ia dinilai sebagai hukum statis adalah kurangnya penggunaan metodologi keilmuan seperti yang dikembangkan di Barat. Olehnya itu pendekatan historis, sosio-kultural, teleologisfilosofis dan pendekatan sains adalah sebuah solusi islamisasi paradigma keilmuan moderen dengan khazanah metodologi hukum Islam klasik. Dengan demikian, paradigma baru hukum Islam adalah hasil yang dicapai dari pendekatan tersebut, yakni paradigma yang memandang hukum Islam secara terpadu, baik sebagai institusi normatif yang mengutamakan nilai dasar kepastian sosiologis maupun hukum Islam sebagai falsafah yang mengutamakan nilai dasar keadilan dan kebenaran

Sangaji Jurnal Pemikiran Syariah dan Hukum 


\section{DAFTAR PUSTAKA}

Abu Zahra, Muhammad. Ushul Fighi, Cet. VI; Jakarta: Pustaka Firdaus, 2000.

Abdul Salam, Zarkasyi. Figh-Ushul Fiqh, Yogyakarta: Lembaga Studi Filsafat Islam, 1994

Ahmad, Noor, Efistemologi Syara" Mencari Format Baru Figh Indonesia, Cet. I; Yogyakarta: Walisongo Press, 2000.

Ali, Mohammad Daud, Hukum Islam Pengantar Ilmu Hukum dan Tata Hukum Islam di Indonesia, Cet. IV; Jakarta: Raja Grafindo Persada, 1998.

Arkoun, M, Essais SurLa Pensee Islamique, Cet.I: Bandung; Pustaka, 2000.

Al-Attas,Syed Muhammad Naquib, Islam and the Philosophy of Science, Cet,I; Bandung: Mizan, 1995.

Effendi, Rusli, Teori Hukum, Cet. I; Ujung Pandang: Hasanuddin University Press, 1991.

Hanafi, Ahmad, Asas-Asas Hukum Pidana Islam, Cet.V; Jakarta: Bulan Bintang, 1993

Haq, Hamka, Filsafat Ushul Figh, Makassar: Yayasan Al-Ahkam, 2000.

Hadi Permana, Syechrul, Peradilan Agama dan Kompilasi Hukum Islam dalam Tata Hukum Indonesia, Cet.I; Jakarta: UI Press, 1999.

Jalaluddin, Filsafat Pendidikan, Jakarta: Gaya Media Pratama, 1998.

Kattsoff, Louis O, Elements of Philosophy, Cet. IV; Yogyakarta: Tiara Wacana, 1989.

Mu"allim, Amir, dan Yusdani, Konfigurasi Pemikiran Hukum Islam, Cet. I; Yogyakarta: UII-Press Indonesia, 1999.

Muhaimin, dan Abd. Mujib, Pemikiran Pendidikan Islam, Kajian Filosofik dan Kerangka Dasar Operasionalnya, Cet. I; Bandung: Trigenda Karya, 1993.

Nasution, Andi Hakim, Pengantar ke Filsafat Sains, Cet. I; Bogor: Litera Antar Nusa, 1989.

Nata,Abuddin, Metodologi Studi Islam, Cet.IV; Jakarta: Raja 
Grafindo Persada, 2000.

Partanto Pius A, Kamus Ilmiah Populer, Surabaya: Arkola, 1994.

Rafiq, Ahmad, Hukum Islam di Indonesia,Cet. III; Jakart: Raja Grafindo Persada, 1998.

Rusli, Nasrun, Konsep Ijtihad al-Syaukani, Relevansinya Bagi Pembaharuan Hukum Islam Di Indonesia, Cet. I; Jakarta: Logos Wacana Ilmu, 1999.

Shiddiqi, Nourouzzaman. Figh Indonesia Penggagas dan Gagasannya, Cet. I; Yogyakarta: Pustaka Pelajar, 1997.

Soekamto, Soejono, Kamus Sosiologi, Cet. I; Jakarta: Rajawali Press, 1983 Suhartono, Suparlan, Konsep Dasar Filsafat Ilmu Pengetahuan, Ujung Pandang: Program Pascasarjana UNHAS, 1997.

Tim Penulis Rosdakarya, Kamus Filsafat, Cet. I; Bandung: Remaja Rosdakarya, 1995.

Yafie, Ali, Ke Arah Kontekstualisasi Fi 